\title{
CUSTODY ORDERS-JURISDICTION AND RECOGNITION*
}

\author{
J.G. CASTEL**
}

Profissor Castel discusses the methods used by Canadian Courts in asserting jurisdiction with respect to custody orders. Where conflicts exist between the statutes of one province, they are resolved by closely analysing the intent and scope of the statute concerned and its applicability to the circumstances of the particular case. With regard to conflicts between custody orders made corollary to a divorce decree under the Divorce Act, and those made pursuant to provincial legislation, the author suggests that no inflexible rule dictating which order would prevail can be given. The merits of the respective federal and provincial claims within this "co-extensive jurisdiction" can only be decided by means of a wide measure of judicial discretion. After enumerating the types of situations where conflicts of jurisdiction may arise and the means used by the courts to assert jurisdiction, Professor Castel argues that the test of ordinary residence should be universally accepted as the most reasonable and realistic basis upon which the courts can exercise jurisdiction, although the courts should still be able to use the criteria of physical presence and domicile if this is in the best interests of the child. With regard to the recognition of foreign custody orders the law, as laid down by the Privy Council in McKee $v$. McKee is that a custody order made by a foreign court does not preclude a Canadian Court from making an order as it sees fit since the foreign order does not have the effect of a foreign judgment and therefore comity does not demand its enforcement. The author, after observing that this approach encourages a wealthy parent to move a child from one jurisdiction to another in search of a court that will award custody to him, notes that the McKee decision is not necessarily binding on Canadian Courts and that it has not consistently been followed. He advocates the exercise of a wide discretionary power by the courts in the best interests of the child, thus following a via media between an a priori refusal to reconsider a foreign order and the making of a new order on the merits of the case.

\section{ASSERTION OF JURISDICTION BY CANADIAN COURTS}

1. Sources

(a) Conflicts among provincial statutes

In Ontario, jurisdiction over custody matters is dealt with in a number of statutes; ${ }^{1}$ "custody" as an issue appears to arise as ancillary to a variety of family situations. In the context of a "custody" problem, the proper statutory framework in which to act will be selected with a view to observing the intent, purpose and scope of each enactment.

Thus in Regina v. Anagnostis ${ }^{2}$ the court was able to decide which of the competing statutes, The Infants Act or The Deserted Wives' and Children's Maintenance Act, applied to the facts. The accused was separated from his wife who had been given custody of their child under an order by a Juvenile and Family Court Judge pursuant to the Deserted Wives' and Children's Maintenance Act. ${ }^{3}$ In March, 1968, he went to a day nursery school where the child had been placed by the mother and took it without her consent. The father then left for Greece with the child and returned in the autumn of the same year. Shortly thereafter, the mother regained custody of the child. The ac-

- This article is a section of a treatise on Canadian Conflict of Laws which Professor Castel is preparing with the financial assistance of the Canada Council. The author wishes to thank Mr. W. Prueter, his research assistant, who helped with the preparation of the section.

** Professor of Law, Osgoode Hall Law School, York University, Toronto.

1 Infants Act, R.S.O. 1970, c. 222; Matrimonial Causes Act, R.S.O. 1970, c. 265; Children's Maintenance Act, R.S.O. 1970, c. 67; Child Welfare Act, R.S.O. 1970, c. 64; and Deserted Wives' and Children's Maintenance Act, R.S.O. 1970 , c. 128 .

2 [1970| 1 O.R. 595 (Co. Ct.).

3 R.S.O. 1960 , c. 105. 
cused was tried on a charge of abduction contrary to s. 236 of the Criminal Code ${ }^{4}$ and during the course of the trial, counsel on his behalf brought a motion for a directed verdict of not guilty on the grounds that by virtue of the Infants Act, ${ }^{5}$ custody was equally in the father and mother and, therefore, the father could not be convicted of the offence charged. It was held that for the purposes of the criminal law a parent is not deprived of his or her rights under the Infants Act by an order made under the Deserted Wives' and Children's Maintenance Act.

The court faced the issue of having to give consideration to the effect of the order and was able to come to the conclusion, based on several decisions, ${ }^{6}$ that it was the primary purpose of the Infants Act to deal specifically with the custody of children, whereas the Deserted Wives' and Children's Maintenance Act deals with this matter only in a subordinate and incidental manner. Moreover, the court was prepared to further note that an order made under the latter Act is not an order made by a Supreme Court or a Surrogate Court, and unless such an order is made by such a court, by virtue of section $2(1)$ of the Infants Act, ${ }^{7}$ the custody and control remain in both the mother and the father.

Thus conflicts which may arise among provincial statutes may be resolved by close analysis of the relation of the particular statute to the circumstances of the case, and the intention of the particular statute.

\section{(b) Interrelationship of provincial and federal jurisdiction in proceedings under the Divorce Act}

A potential conflict of constitutional jurisdiction exists between proceedings under the Divorce Act ${ }^{8}$ and provincial statutory provisions. This results from section 91(26) of the British North America Act which gives the federal Parliament exclusive competence over marriage and divorce. Proceedings instituted pursuant to section $11(1)(c)$ of the Divorce Act potentially constitute an infringement on the provincial rights of custody as they are embodied in section 92(13) of the B.N.A. Act, as part of the provincial jurisdiction over property and civil rights.

The courts have clearly had to work out a modus vivendi in this area, and expert opinion favours the view that the federal Parliament cannot legislate with respect to custody simply as a civil right, but may where the issue of custody arises as a necessary adjunct to the

- Now see R.S.C. 1970, c. C-34, s. 250.

5 R.S.O. 1960, c. 215.

- See also Yewchyn v. Yewchyn [1951] O.W.N. 101 (C.A.); and Re Chartrand [1965] 1 O.R. 647 (Surr. Ct.).

'Supra, n. 1.

- R.S.C. 1970, c. D-8. In an article by L. B. Campbell, Custody of Children,(1962) Law Society of Upper Canada, Special Lectures 173 at 178 it is said that:

The jurisdiction of the Supreme Court of Ontario was increased in 1930 when the Parliament of Canada passed the Divorce Act (Ontario), 1930, which introduced into that province:

"1. The law of England as to the dissolution of marriage, as that law existed on the 15th day of July, 1870 , in so far as it can be made to apply in the Province of Ontario, and in 80 far as it has not been repealed as to the Province, by any Act of the Parliament of the United Kingdom, or by any Act of the Parliament of Canada, or by this Act, and as altered, varied, modified or affected, as to the Province, by any such Act, shall be in force in the Province of Ontario."

It is settled that the practice in the English Courts in divorce matters, even where it was prescribed by statute, and not merely by Rules of Court was not introduced into the Province by the Dominion Act of 1930 (Davies v. Davies [1940] O.R. 267). It is the substantive law of England as of the said date which was introduced. It will always remain a problem to seek out what was the substantive law as of the said date and what are mere matters of procedure. The subject matter of practice falls within the right of the provincial legislature to deal with "property and civil rights in the province." 
dissolution of a marriage. Implicit in this statement is a recognition of the fact that both the federal and provincial legislatures have coextensive jurisdiction in so far as their respective jurisdictions relate to custody..$^{9}$

It would appear inat constitutionally, the powers given to the provinces by way of section 92(13), and the powers given to the federal legislature by way of section $92(26)$ of the British North America Act, in their relation to custody, are inseparable, and accordingly, it is not ultra vires the Parliament of Canada to provide for orders corollary to divorce with respect to custody and maintenance.

It must also be noted that a custody order made in one province under the Divorce Act as a result of the dissolution of the marriage is enforceable, after registration, in all other provinces and territories of Canada. ${ }^{10}$

The courts have distinguished between a final and an interim order for custody under the Act pending the hearing and determination of the petition. ${ }^{11}$

In Papp v. Papp et al. ${ }^{12}$ the Ontario Court of Appeal analyzed the problem of the interim custody order and the question of whether a Master could be assumed to be acting within his authority in granting such an order. It was decided that under section $10(\mathrm{~b})$ of the Divorce Act, the court having jurisdiction to grant relief in respect of divorce is also given jurisdiction to make an interim order for the maintenance and custody of the children of the marriage. The proper interpretation of section 19(1) of the Act, which allows the court to make rules "applicable to any proceedings under this Act within the jurisdiction of the court", is sufficiently wide to permit delegation to the Master of authority with respect to interim custody.

The "co-extensive jurisdiction" theory must of necessity be further defined, since it is important to set out the guidelines for the application of the federal jurisdiction.

Bray v. Bray ${ }^{13}$ explains the proper balancing of provincial and federal claims to jurisdiction.

In that case Harold Bray, a resident of the Province of Quebec, was the subject of an order by the Montreal Social Welfare Court. In proceedings in an undefended divorce action launched in Ontario, based on grounds of cruelty and separation, the mother attempted to convince the court that pursuant to the Divorce Act, it had jurisdiction to award custody.

The court, while recognizing the "co-extensive jurisdiction" theory, nevertheless severely restricted the application of corollary federal jurisdiction. Wright J. interpreted the Divorce Act as follows: ${ }^{14}$

I think that all the legislation does with regard to custody is to recognize and adopt in divorce proceedings, the existing jurisdiction and procedures of the provincial

\footnotetext{
- Niccolls v. Niccolls and Buckley [1969] 68 W.W.R. 307 at 309. The British Columbia Supreme Court relied on a remark made by Duff C.J. in Reference as to Constitutionality of Adoption Act; Children's Protection Act; Children of Unmarried Parents Act; Deserted Wives' and Children's Maintenance Act [1938] S.C.R. 398, 71 C.C.C. $110,[1938] 3$ D.L.R. 497 at 498.

10 The Divorce Act, supra, n. 8 8. 15.

11 ld. s. 10(b).

12 [1970] 1 O.R. 331 (C.A.). See also Johnson v. Johnson et al. [1972] 1 O.R. 212 (C.A.).

13 [1971] 1 O.R. 232 (H.C.), 15 A.L.R. (3d) 40, 2 R.F.L. 282.

11 Id. at 237.
} 
Courts under provincial law to award custody, and not to disturb or alter either the character of the jurisdiction or the grounds on which it is exercised. It is not seeking conflict. I do not think that an order registered under s. 15 of the Act is neces. sarily effective in other Provinces so far as custody is concerned or that it deprives other provincial Courts of continuing jurisdiction and duty with regard to the custody of children within the Province at any time and from time to time.

Implicit in the reasoning of Wright $\mathrm{J}$. is an acceptance of the view that the custody provisions of the Divorce Act are permissive and supplementary to existing provincial legislation, and accordingly the court in this undefended divorce action should refuse to exercise its discretion when the child, in respect to which the order is asked, resides in another province and is subject to an existing custody order made in that province.

Wright J. considered the applicability of Papp v. Papp et al.15 and agreed with the finding of the Court that custody could be validly awarded under the Divorce Act, but disagreed with the conclusion that a custody order made pursuant to this Act would prevail over the exercise of the prerogative of the judiciary in another province in which the child was already subject to an order. The question of jurisdiction need not concern the court unduly since each jurisdiction in which the child was present could and should be able to make orders regarding its custody, notwithstanding the terms of a divorce decree. Although Wright J. recognized that he must operate within the established doctrines of constitutional law relating to federal jurisdiction, he clearly favoured the injection of a wide measure of judicial discretion in custody matters, as opposed to any inflexible rule which would serve to dictate which order would prevail where federal and provincial orders were in conflict.

In Emerson v. Emerson ${ }^{16}$ Wright J. stated that a divorce decree giving corollary relief in respect of children of the marriage does not inhibit the exercise of any ordinary jurisdiction in another province for the custody, care or maintenance of any child in that province. Custody does not depend upon marriage or divorce, a field properly occupied by federal legislation. Rather, the child is entitled to the parental protection of the provincial superior courts exercising the prerogative of the Crown in the right of the province as parens patriae. ${ }^{17}$ One jurisdiction does not necessarily destroy the other. Both, in the matter of the welfare of the children, can stand together with the ultimate responsibility, at any particular time, on the courts where the child is. Wright $\mathrm{J}$. also pointed out that although an Ontario court is not deprived of jurisdiction over infants by the terms of a decree issued in another province, its jurisdiction is not lightly exercised without regard to what has already been determined after trial elsewhere. Those who invoke it must satisfy the court that its order is needed for the welfare of the child.

In Johnson v. Johnson et al. ${ }^{18}$ it was held by the Ontario Court of Appeal that a court, in divorce proceedings, has jurisdiction to entertain an interim custody application notwithstanding that immediately prior to the application the husband, a resident of Ontario, sensing defeat,

is Supra, n. 12.

${ }^{26}$ [1972] 3 O.R. 5.

"See also O'Neill v. O'Neill (1971) 19 D.L.R. (3d) 731, 5 R.F.L. 98.

in Supra, n. 12. 
took de facto custody and left the jurisdiction. By way of obiter the Court of Appeal also stated that under section 10 of the Divorce Act an order can be made where the party against whom the order is sought to be enforced is beyond the provincial boundaries.

\section{Cases In Which Jurisdiction Will Be Asserted}

Elash v. Elash ${ }^{19}$ enumerates four types of situations where conflicts of jurisdiction may arise.

(a) Where the infant is within the territorial jurisdiction of the court

The modern approach to the question of jurisdiction is that the physical presence or residence of the child within the jurisdiction, irrespective of its domicile, is sufficient to give the court authority to make an order respecting custody. ${ }^{20}$

Thus, in Masterson v. Masterson, ${ }^{21}$ the Saskatchewan Court of Appeal rejected the exclusive test of domicile which was laid down in Cody v. Cody. ${ }^{22}$ Gordon J.A. stated: ${ }^{23}$

It is of course admitted that the domicile of the husband, the wife and the two children is in the Province of Ontario and counsel for the appellant cited the case of Cody v. Cody, [1927] 3 D.L.R. 349, 21 Sask. L. Rev. 391, as authority for the contention that 'the only court with jurisdiction over the custody of the infant is the court of the domicile of the infant'. With every deference we do not think that this is the law. The case relied on in that decision is that of Re McGibbon (1918), 39 D.L.R. 177, 13 Alta. L. Rev. 196, and we do not think that this case bears out this contention.

Physical presence or residence of the child within the province is not an exclusive test of jurisdiction. The circumstances may be such that the court will refuse to deal with the question of custody, as for instance, where all the parties are domiciled abroad and the child was forcibly brought within the province. As the Ontario Court of Appeal pointed out in Re Ridderstroem and Ridderstroem: ${ }^{24}$

... in these days of quick transportation by air, including the facilities for hasty removal of children from one country to another, that the Courts of the English countries operating under the common law system will look with great disfavour on any attempt to flout the invoked jurisdiction of a proper Court in a foreign country unless the paramount interests of the child demand that such be done-and such paramount interest of the child is to be demonstrated by cogent, convincing proof, that to leave the child with the parent which had custody in the country of original jurisdiction or the parent to whom the foreign jurisdiction has awarded custody, will seriously endanger the child's welfare.

(b) Where the infant is beyond the territorial jurisdiction but the person in control is within the jurisdiction

As the Saskatchewan Court of Queen's Bench pointed out in Elash v. Elash:25

19 (1964) 43 D.L.R. (2d) 599 (Sask. Q.B.).

${ }^{20}$ E.g., McKee v. McKee [1951] 2 D.L.R. 657 at 661, [1951] A.C. 352 at 360, [1951] 2 W.W.R. (N.S.) 181 at 186 (P.C.); Re Masterson et al., Masterson v. Masterson [1948] 2 D.L.R. 696 at 699, [1948] 1 W.W.R. 642 at 645 (Sask. C.A.); Heslop v. Heslop [1958] O.W.N. 137, [1958] O.R. 183, (1958) 12 D.L.R. (2d) 591 (C.A.); Rioux v. Rioux (1936) 36 D.L.R. (2d) 446 at 447, 40 W.W.R. 251 at 252 (Man. C.A.); Elash v. Elash, supra, n. 19 at 602; Neilsen v. Neilsen [1971] 1 O.R. 541, 16 D.L.R. (3d) 33 (H.C.); and Mandel v. Mandel (1971) 5 R.F.I. 50 (Man. Q.B.).

21 Supra, n. 20.

22 [1927] 1 W.W.R. 603, 21 Sask. L.R. 391, [1927] 3 D.L.R. 349 (Sask. K.B.), based on Re McGibbon sub nom. Re M. (1918) 13 Alta. L.R. 196, [1918] I W.W.R. 579, (1918) 39 D.L.R. 177 (C.A.).

23 [1948] 2 D.L.R. 696 at 699.

24 [1972] 2 O.R. 113 at 113,114 (C.A.).

25 Supra, n. 19 at 602 See also Re McGibbon, supra, n. 22; Re Harding [1929] 2 D.L.R. 623, 63 O.L.R. 518 (C.A.); Re Sutherland [1950] O.W.N. 404 (H.C.); Warren v. Warren (1958) 25 W.W.R. 391 (Sask. Q.B.); and Re Vadera and Vadera (1972) 23 D.L.R. (3d) 289, [1972] 1 O.R. 441. 
In all questions relating to the custody of infants the rules of equity prevail: Queen's Bench Act, 1960 (Sask.), c. 35, s. 44, para. 11. The decrees and orders of the Court. of Chancery (other than those respecting land) operated in personam; and in the exercise of its inherent Chancery jurisdiction this court has the power to order a person who is exercising actual control over an infant, and who is residing within the jurisdiction and thus subject to the control of the Court, to bring the infant into our territorial jurisdiction. Residents of this province cannot shed this Court's jurisdiction over infants by the simple expedient of keeping them in another jurisdiction, such as a neighbouring Province. If such a person when so ordered failed to bring the infant into the jurisdiction then of course his obedience can be compelled by proceedings to commit him for contempt or by sequestration proceedings against his property and effects within the jurisdiction.

(c) Where the infant while physically outside the territorial jurisdiction is domiciled in this province

Since the Masterson ${ }^{26}$ decision in 1948, Canadian courts have reacted strongly against domicile as the exclusive test of jurisdiction. For instance, in Re Walker and Walker, ${ }^{27}$ the common situation arose where one of the parents removed a child from the jurisdiction, in this case from Ontario to Massachusetts.

Pennell J. of the Ontario High Court, in a ruling on a preliminary question as to jurisdiction on a motion for an order with respect to custody of children under the Infants Act, ${ }^{28}$ reasoned that since children normally take the domicile of their father who, in this instance, was domiciled in Ontario, then by the test of domicile, jurisdiction would normally rest with the court to deal with the issue of custody. However, he said:29

The question whether domicile or 'ordinary residence' is the test of jurisdiction is fairly open to argument. It is a noteworthy circumstance that the Alberta Court of Appeal in the case Re McGibbon held that it had jurisdiction over an infant who was domiciled in that Province even though not resident nor physically present there. I venture, very respectfully, to suggest that the trend seems to be against domicile as the test. It is familiar law that the rule for ascertaining domicile turns on the intention of the person to establish a permanent home. In this age of mobility the rule produces unrealistic and artificial results. It is of interest to notice that for all purposes of establishing the jurisdiction of the Court to grant a decree of divorce under the Divorce Act, 1967-68 (Can.), c. 24, the domicile of a married woman shall be determined as if she were unmarried. That provision deals only with divorce, but it seems to me that it is indicative of the modern approach to avoid the severe feature of the common law doctrine of domicile as a test of jurisdiction.

The remarks of Pennell J. are well supported if we consider the trend currently identifiable in England towards a rejection of domicile and an adherence to the easier to apply test of "ordinary residence". ${ }^{30}$

Where an infant is "ordinarily resident" is a simple question of fact at any particular moment in time. Moreover, the "ordinary residence" cannot be changed simply by the unilateral act of one parent leaving the matrimonial home and taking the child along. Thus, in $\operatorname{Re~P.~(G.E.)~}$ (An Infant), ${ }^{31}$ the Court of Appeal held that the English Court of Chancery, representing the Crown as parens patriae, has jurisdiction

\footnotetext{
${ }^{26}$ Supra, n. 20.

27 [1970] 3 O.R. 771 (H.C.).

28 Supra, n. 1.

29 Supra, n. 27 at 774.

${ }^{30} \operatorname{Re~P.~(G.E.)~(An~Infant)~[1965]~} 1$ Ch. 568 (C.A.) which involved a six-year-old boy ordinarily resident in England who was taken to Israel by his father without the consent of his mother. The issue before the court was whether the English court had jurisdiction over the child when he was not physically present in England. See also Johnstone et al. v. Beattie (1843) $10 \mathrm{Cl}$. \& Fin. 42 at 119, 120 per Lord Campbell, 8 E.R. 657 .

31 Id.
} 
to make an order for the custody, education and maintenance of a child ordinarily resident within the jurisdiction, although the child is neither a British subject nor physically present in the country when the proceedings are initiated. An alien infant ordinarily resident in England owes allegiance to the Crown and, as a corollary to that allegiance, has a right to protection from the Crown and consequently to the parental jurisdiction of the Crown exercised through the High Court. Their Lordships ${ }^{32}$ were of the opinion that the test of ordinary residence is to be preferred to that of domicile, as the test of domicile is archaic and artificial and would produce strange results if applied in the context of a jurisdiction which historically is closely connected with allegiance.

In Nielsen v. Nielsen ${ }^{33}$ the Ontario High Court appears to echo this view in resolving interprovincial conflicts of jurisdictions. ${ }^{34}$

Galligan J. was of the opinion that the court of the place of the child's ordinary residence as well as the court of the place where it is physically present have jurisdiction to determine issues concerning the welfare of the child, including its custody, unless there exist special circumstances which indicate that the return of the child to such "ordinary residence" would inflict serious harm on it. Galligan J. defined ordinary residence as "the last place in which the child resided with his parents" 35 and added that ordinary residence cannot be changed by the surreptitious removal of the child from the ordinary residence.

Jurisdiction based on "ordinary residence" is likely to lessen interprovincial interference, and result in wider recognition being given abroad to an order issued by the court of the child's ordinary residence. Moreover, the certainty of the "ordinary residence" test of jurisdiction would go far towards resolving the kinds of difficult jurisdictional conflicts typified by the case of Walker v. Walker, ${ }^{36}$ which the "domicile" approach served to complicate.

(d) Where the person controlling the infant and the infant himself are beyond the territorial jurisdiction of the court

32 Lord Denning M.R., Lords Pearson and Russel L.JJ.

${ }^{33}$ Supra, n. 20. Note that in Re Baggio (1971) 3 R.F.L. 74 (N.S. Co. Ct.) the court held that by virtue of 8. 8 of the Infants Custody Act, R.S.N.S. 1967, c. 145, it had jurisdiction to deal with the custody of a child resident within its district. See also O'Neill v. O'Neill supra, n. i7, where the Nova Scotia Supreme Court held that it had jurisdiction to vary a custody order made in Ontario independently of $8.11(2)$ of the Divorce Act on the ground that the child was now resident in Nova Scotia; and Re Wright (1965) 49 D.L.R. (2d) 460 (N.S.S.C.).

34 Reference was made to the English case of $R e H$ (Infants) [1966] \& W.L.R. 381, aff'd at 393 which concerned two American boys who were brought to England by their mother without the knowledge of either the father or the Supreme Court of New York State before which custody proceedings were pending. Applying the test of "ordinary residence". Cross $\mathrm{J}$. held that as the place of ordinary residence was the State of New York, the proper court to determine the issue of custody would be the State of New York. Sec also $\operatorname{Re} E$ (D) (An Infant) [1967] \& Ch. 287, aff'd at 761; and ProssorJones v. Prossor-Jones (1972) 7 R.F.L. 150 (Man. Q.B.).

35 (1971) 16 D.L.R. (3d) 33 at 37, 38, 39 (Ont. H.C.).

${ }_{36}$ Supra, n. 27. The Divorce Act, supra, n. 8 s. $5(1)(b)$, provides that a petition can be entertained if: either the petitioner or the respondent has been ordinarily resident in the Province for at least one year immediately preceding the presentation of the petition and has actually resided in that Province for at least ten months of that period.

However, the meaning of "ordinary residence" used in custody cases is not exactly the same as that used in the Divorce Act. This is regrettable, although to affix any set period of residence might inflict some hardship in borderline cases.

Note that more than ten years ago, the English Parliament embarked on a study of the problem of conflicts of jurisdiction affecting children in England and Scotland. In its report (Report of the Committee on Conflicts of Jurisdiction Affecting Children (1959), Cmnd 842), the Committee was of the opinion that it was wrong to seek a solution in an exclusive jurisdiction. In its view, the preeminent jurisdiction should be the court of the ordinary residence of the child rather than the court of its domicile. For a criticism of the concept of ordinary residence, see Gareth H. Jones, Conflicts of Jurisdiction in the United Kingdom Affecting Children, (1960) 9 I.C.L.Q. 15 esp. at 21; Kahn.Freund (1960) 23 Mod. L. Rev. 64. Compare American Restatement of the Law. Conflict of Laws $2 d$ (1971) s. 79. 
This particular situation deserves special consideration in the light of the conflicting case law.

The now outdated approach rejecting jurisdiction is set out in the case of Hannon v. Eisler ${ }^{37}$ wherein it was indicated that in a number of cases ${ }^{38}$ it was clear that a court had no jurisdiction to adjudicate upon the custody of children who are not present within the territory over which the court has jurisdiction unless the person having authority over such children is within such territory.

The Hannon v. Eisler decision was partly based on the opinion of the court with respect to the difficulty of enforcing an order in such circumstances.

The Saskatchewan Court of Queen's Bench also recognized the importance of the question of enforceability in Elash v. Elash. ${ }^{39}$ However, the court was prepared to hold that the inability to enforce such an order is not conclusive in terms of a court asserting its jurisdiction; it is only a factor to which must be attached "great weight". The making of the order is discretionary. This is an excellent approach, and as Lord Cranworth pointed out: 40

It may be that the child is placed under such circumstances that the jurisdiction of the Court cannot be exercised over it because no order I might issue could be enforced; but in that case there is not a want of jurisdiction, but a want of the power of enforcing it. . . Therefore, it is putting the matter on a wrong footing to say, because the child is out of the jurisdiction, that the Court has no jurisdiction. In such a case, anybody might, by merely withdrawing himself from the jurisdiction, escape all liability to it.

A perusal of Canadian decisions reveals that in this situation custody orders have rarely been made and then only under special circumstances.

\section{Conclusion}

The conclusion to be drawn from each of the specific factual situations as set out in Elash v. Elash ${ }^{41}$ is that the courts which attempted to resolve the problems set out under each of the four headings, while acting in the best interests of the child, were searching for a basis on which they could assert their jurisdiction, and they were uncertain of the approach or theory of jurisdiction on which to depend. The test of ordinary residence, as it has been set out in several recent English and

${ }^{37}$ [1955] 1 D.L.R. 183 at 191, 192, 62 Man. R. 440 at 451, 13 W.W.R. (N.S.) 565 at 575 (C.A.).

30 Dickson v. Dickson [1944] 2 D.L.R. 396 (Sask. C.A.); Cleaver v. Cleaver, [1949] 4 D.L.R. 367, [1949] O.W.N. 640 (C.A.); Re Tokarchuk Infants (1952) 5 W.W.R. (N.S.) 19 (Alta. S.C.) at 21 per Egbert J.; and Keel v. Keel (1952) 7 W.W.R. (N.S.) 518 (Sask. Q.B.) at 519 per Thomson J.

39 Supra, n. 19 at 604.

${ }^{40}$ Hope v. Hope (1854) 4 De G.M. \& G. 328 at 345-6, 43 E.R. 534 at 541. Wilson J., as he then was, in his particularly informative judgment in Nordwall v. Nordwall (1960) 20 D.L.R. (2d) 493, 28 W.W.R. 260 (B.C.S.C.) reached the conclusion which is stated at 495 (D.L.R.), 262 (W.W.R.) as follows:

This, I think, is the true rule, stemming from the judgment of Lord Cranworth L.C. in Hope v. Hope (1854) 4 De G.M. \& G. 328, 43 E.R. 534 in which it was distinctly held that inability to enforce an order for custody of children residing abroad was not an absolute bar to making such an order, but a factor to be considered by the Court in deciding whether or not to exercise its discretion in favour of making such an order; that the fact that the children and the person having control of the children were not within the territory where the Court's orders could be enforced in personam did not deprive the Court of jurisdiction, but was a matter to be weighed in exercising discretion.

See also Cody v. Cody, supra, n. 22; Goforth v. Goforth [1929] I D.L.R. 58, [1928] 3 W.W.R. 483 (Alta. S.C.); Clifion v. Clifton [1949] I D.L.R. 597. [1949] 1 W.W.R. 125 (B.C.S.C.); Keel v. Keel, supra, n. 38; Harben v. Harben [1957] 1 All E.R. 379; Bedrin v. Bedrin (1962) 39 W.W.R. 639 (B.C.S.C.); Zien v. Zien (1962) 38 W.W.R. 254, (1962) 36 D.L.R. (2d) 478; Chung v. Chung (1966) 60 D.L.R. (2d) 526 (N.S.C.A.); Kilpatrick v. Kilpatrick [1930] 1 D.L.R. 288, [1929] 3 W.W.R. 463, 42 B.C.R. 88 (B.C.S.C.) and Munroe v. Munroe [1942] 3 W.W.R. 656 (B.C.S.C.). In Joyce v. Joyce (1966) 57 W.W.R. 126 (B.C.S.C.), the court of the Province where the children were domiciled, but not resident at the time, declined to exercise jurisdiction.

« Supra, n. 19. 
Canadian cases, should be universally accepted as it gives the courts a very reasonable and realistic basis for exercising their jurisdiction in custody cases. However, ordinary residence must not be the only basis. In some cases, depending upon the circumstances, the courts should still be able to assert jurisdiction on the basis of physical presence or domicile. In other words, each of these grounds of judicial jurisdiction provides a reasonable and suitable basis upon which a court may proceed in a proper case.

Of course, when domicile is used as a basis for jurisdiction, certain questions of law and fact will inevitably arise, especially questions of intention. Jurisdiction based on physical presence is not free from criticism either, as it could encourage legal kidnapping, but where the residence of the child is uncertain, physical presence is a necessary substitute. One must also recognize that the test of ordinary residence is not completely free from criticism. In some cases it may be difficult to distinguish between genuine and tactical changes of residence. Furthermore, residence, as opposed to physical presence, seems to demand the formation of an intention, no matter how weak. Are small children capable of such an intention? Are we not re-introducing the notion of domicile under the cover of residence?

A child may, in theory, have several residences. In most cases, obviously, the residence of the child will be that of the parent who could be the "kidnapping parent". The definition adopted in Nielsen $v$. Nielsen ${ }^{42}$ as the last place in which the child resided with his parents would prevent this from happening.

This is an area of the law where the exercise of jurisdiction must, of necessity, involve a certain amount of discretion on the part of the court. Nielsen v. Nielsen would seem to offer the best approach. The court should only take jurisdiction if it is in the interest of the child to do so. In custody cases, because the welfare of the child is so important and time is of the essence, prolonged disputes on the technical and initial questions of jurisdiction must be avoided, since they would be detrimental to the child and the parents and to the reputation of the law. For these reasons it is not advisable to adopt an exclusive test of jurisdiction.

\section{RECOGNITION OF FOREIGN CUSTODY ORDERS}

The most authoritative case setting out guidelines for the recognition of a foreign custody order is McKee v. McKee. ${ }^{43}$ This case serves as a useful vehicle to indicate the nature of the problem, despite the fact that the rationale given by the court is obscured by the over-riding importance given to the "welfare of the child" policy of both the Supreme Court and the Privy Council.

From a complicated fact situation, the question resolved itself into a consideration of the effect to be given to a custody order of a California Court. The material facts were that a competent court had awarded custody to the mother (California decree), and the father de-

\footnotetext{
12 Supra, n. 20.

43 Supra, n. 20, noted (1948) 26 Can. Bar Rev. 1368 at 1372, (1949) 27 Can. Bar Rev. 99, (1951) 29 Can. Bar Rev. 536. Accord: Heslop v. Heslop, supra, n. 20; Re Wright, supra, n. 33; Menasce v. Menasce (1965) 48 M.P.R. 281, 40 D.L.R. (2d) 114 (P.E.I.S.C.). See also Re C. (1922) 67 D.L.R. 630 at 633, [1922] 1 W.W.R. 1196 (Man. R.C.); and Re Gay [1926] 3 D.L.R. 349 (Ont. C.A.).
} 
liberately evaded that order by removing the child to another jurisdiction (Ontario).

The Privy Council articulated four main rules which are to guide the Canadian courts in their consideration of custody orders made by a competent foreign court. ${ }^{44}$

(1) The paramount consideration, regardless of other issues, is the welfare of the infant and the matter of custody is peculiarly within the discretion of the trial judge.

(2) The Ontario courts have jurisdiction to deal with the custody of an infant resident in Ontario notwithstanding that his divorced parents, contending for his custody, are resident and domiciled in another country.

(3) An order of a foreign court as to the infant's custody is not binding on an Ontario court which is required to exercise an independent judgment in the matter having regard to relevant factors one of which would be, of course, the foreign order.

(4) The trial judge's opinion on custody, formed in the light of all relevant factors and after giving due weight to all competing considerations should not be disturbed unless he has acted on some wrong principle or disregarded material evidence. Hence, where he awards custody to the father in pursuance of primary concern for the welfare of the child, and after weighing a foreign order for custody in favour of the mother and taking into account that the father brought the child into Ontario to avoid compliance with the order, and also broke an agreement with the mother not to remove the infant from the United States without consent of the other parent, his order as to custody should stand. He was entitled to make an independent inquiry into the matter from the standpoint of the child's best interests.

On the basis of these reasons the court not only quickly settled the issue of "jurisdiction", but also indicated that upon the basis of the consideration of the welfare of the child, the Canadian court ought not to blindly follow an order made by a foreign court. In fact, if the foreign judgment was to be regarded "merely as evidence", and if the matter were to come before the court of Ontario within a very short time of the foreign judgment, and there were no new circumstances to be considered, the court might refuse jurisdiction upon the basis that it was not in the infant's best interest to hear the case. ${ }^{45}$

The Privy Council affirmed the view that a valid foreign order does not have the effect of a foreign judgment, and hence comity does not demand its enforcement, but only that it be given great weight in determining the proper custody.46 In other words, a custody order made by a foreign court does not preclude a Canadian court from making a custody order in Canada as it thinks fit. To so hold is to recognize that a foreign decree of custody is not in itself final or binding. It determines nothing as to the custody of the infant, save at the time of its making, for it reserves liberty to either party to apply for variation. Therefore " $[t]$ he courts of this country must always exercise the jurisdiction conferred upon them in regard to the custody of infants within this jurisdiction according to the laws of this country."47

In McKee, at the trial level, Wells J.48 dismissed the California judgment firstly on the basis of the well-known principle that a foreign judgment may not be relied upon in a subsequent action unless it is final, binding and not subject to variation. Secondly, Wells $J$. felt that

\footnotetext{
11 See headnote [1951] 2 D.L.R. 657.

is Id. at 665 .

${ }^{16}$ See also Re Davis (1894) 25 O.R. 579; and In Re Snyder; Snyder v. Snyder [1927] 2 W.W.R. 240, 38 B.C.R. 336, [1927] 3 D.L.R. 151 (C.A.).

"Re Gay, supra, n. 43 at 351 .

4" [1948] O.R. 658.
} 
the California court had acted without jurisdiction since the infant was neither resident nor domiciled within that state, and thirdly that even though the father had sought out the California forum as plaintiff and subsequently had prosecuted several appeals, he was not estopped from denying the validity of the California judgment since the court had acted without jurisdiction.

There is further discussion in the $M c K e e$ case of a subsequent question which arises in the case of jurisdiction.

If the Canadian court will exercise its jurisdiction over an infant like McKee, to what extent should it interfere beyond the stage of assuring that the infant be returned to its own country? This question was the subject of debate in the Court of Appeal, and it was the feeling of Robertson C.J.O. that: 49

The Courts of this Province should leave the dispute regarding the custody of the infant to the Courts of the country to which these people belong. It is not a question of jurisdiction, but rather one of comity between friendly nations. The United States has jurisdiction over its own subjects, whether at home or abroad. The Courts of this Province have jurisdiction over persons while they are within the Province, although they may be the subjects of a foreign power, but in the special circumstances of this case, a proper observance of the comity of nations, in my humble opinion, requires that the Courts of this Province should not exercise their jurisdiction over this infant than to assure his return to the country to which he belongs.

In Robertson C.J.O.'s view, there existed a grave impropriety in upholding a claim made to the custody of an infant who is a subject of a neighbouring and friendly country, by a person who has brought the infant into this province in breach of an agreement not to remove the infant from the country to which that infant belongs, and solely for the purpose of evading an order of the courts of that country.

Robertson C.J.O.'s adherence to the comity of nations theory had a sound basis in English law, ${ }^{50}$ but clearly the welfare of the infant was a sufficient reason in this instance to prompt the court to reject it when circumstances had changed and new evidence was available for the court to consider.

It may be concluded, that when the case finally did reach the Privy Council, insufficient consideration was given to Robertson C.J.O.'s view.

Lord Simonds essentially dismissed Robertson C.J.O.'s position when he said: 51

It is possible that a case might arise in which it appeared to a court, before which the question of custody of an infant came, that it was in the best interests of that infant that it should not look beyond the circumstances in which its jurisdiction was invoked and for that reason give effect to the foreign judgment without further enquiry. But it is the negation of the proposition, from which every judgment in this case has proceeded, namely, that the infant's welfare is the paramount consideration, to say that where the trial judge has in his discretion thought fit not to take the

\footnotetext{
19 Id. at 672 .

so Nugent v. Vetzera (1866) L.R. 2 Eq. 704 (headnote):

The Court will not from any supposed benefit to infant subjects of a foreign country, who have been sent to this country, for the purposes of education, interfere with the discretion of the guardian who has been appointed by a foreign Court of competent jurisdiction, when he wishes to remove them from England in order to complete their education in their own country.

However, this position changed with the decision of Re B.'s Settlement [1940] $1 \mathrm{Ch}$. 54, where Morton J. noted that the English Guardianship of Infants Act modified the principle of complete recognition of a foreign guardian's status.

In Ontario it would appear that a foreign guardian has no absolute rights, but the fact of his appointmen is to be given great weight in determining proper custody. See Hope v. Hope, supra, n. 40 followed in Re Davis (1894) 25 O.R. 579; and Re Chisholm (1913) 13 D.L.R. 811, 47 N.S.R. 250.

st McKee v. McKee [1951] A.C. 352 at 363, 364.
} 
drastic course above indicated, but to examine all the circumstances and form an independent judgment, his decision ought for that reason to be overruled. Once it is conceded that the Court of Ontario had jurisdiction to entertain the question of custody and that it need not blindly follow an order made by a foreign court, the consequence cannot be escaped that it must form an independent judgment upon the question, though in doing so it will give proper weight to the foreign judgment. What is the proper weight will depend upon the circumstances of each case.

The result, therefore, is that the "comity of nations" approach as originally adopted by Robertson C.J.O. at trial, and affirmed by Cartwright J. on appeal, has been restricted to apply only to those situations where there has been no conspicuous change of circumstances since the making of the foreign order.

It seems arguable that Canadian courts, when faced with a foreign order, should have jurisdiction only in cases where an infant is left unprotected. Implicit in this approach is both a recognition that the now outmoded "comity of nations" doctrine still has some applicability, and an affirmation of the view that the courts best able to deal with the question of an infant's custody are the courts of its own country.

A flexible approach must be adopted by the courts in order to discourage the wealthy parent from moving the child from one jurisdiction to another until he finds a court that will award him custody. In England, the courts have taken a dim view of "legal kidnapping". In some cases, they have sent the child back to the country from which it was taken without fully examining the merits of the dispute, provided the child will come to no harm if it is sent back.

As Cross J. pointed out: 52

The sudden and unauthorized removal of children from one country to another is far too frequent nowadays, and, as it seems to me, it is the duty of all courts in all countries to do all they can to ensure that the wrongdoer does not gain an advantage by his wrongdoing. ... In infancy cases the welfare of the infant is, of course, the chief consideration, but it is far from being the only consideration.

In this connection reference should be made to a recent decision of the British Columbia Supreme Court in Re Lyon and Lyon ${ }^{53}$ where Kennedy J. noted that McKee v. McKee need not be regarded in Canada as necessarily binding upon a judge in adjudicating a custody suit. He said:54

I might digress here and state that I firmly believe in the principle of what is best for the child as I am sure does every judge in Canada. That is the primary principle that we are all concerned with. However, in this case, I think there is a very important issue raised in this matter that goes to the general administration of justice in Canada and the judicial comity of our Canadian Courts. Notwithstanding my most deferential respect for the decision of the Privy Council in McKee v. McKee which, of course, we all respect very highly, I do not think today that we are absolutely com. mitted to follow such decision as we now have the Supreme Court of Canada which is, of course, paramount in our country so far as judicial decisions are concernednevertheless we certainly respect this decision. I prefer to accept the reasoning in the majority decision of the Supreme Court of Canada in the very same case, and particularly the reasoning of Cartwright J., as he then was, in delivering the majority judgment. I think, with great respect, the Supreme Court of Alberta, where the matter is now pending on the question of custody, is the proper forum for the adjudication

53 Re H. (Infants) [1966] I W.L.R. 381 at 389, 393; aff'd at 393; cf. Re E(D) An Infant [1967] 1 Ch. 287; aff'd at 761 where compelling reasons existed why the child ought not to be sent back.

33 (1969) 10 D.L.R. (3d) 287 (B.C.S.C.).

34 Id. at 289. 
of this question. As far as I am concerned, I refuse jurisdiction in this case. The petition is dismissed. (emphasis added).

It seems that, contrary to what Lord Simonds said in the case of $M c K e e^{55}$ there is a via media between the abdication of jurisdiction and the consideration of the case on its merits.

To sum up:

(1) A foreign decree is, by the "comity of nations", entitled to considerable weight but has no binding effect in the courts of another jurisdiction. .6

(2) The application of judicial creativity together with the adoption of the viewpoint that McKee v. McKee need not be followed leaves considerable flexibility for a court to refuse jurisdiction in custody matters where a foreign decree is at issue except in the very exceptional or altered circumstances where the child is endangered in some way. .7

(3) The Ontario courts accept that a foreign order merely raises a prima facie case which the party claiming custody has to displace. ${ }^{58}$

(4) A basic distinction exists between a foreign judgment and a foreign order, and since an order providing for the custody of an infant cannot in its very nature be final, it does not have any binding extraterritorial effect.59

Within these rules the courts, exercising the highest degree of discretion, may, depending upon the circumstances of the case, either give effect to the foreign order absolutely or indirectly by sending the child back to the court that made it, without fully going into the merits of the case, or refuse to recognize the foreign custody order and make a new one after a full examination of the merits of the case. In this area of the law, because of the interests involved, the courts should never be absolutely bound to enforce a valid foreign custody order.

\footnotetext{
ss Supra, n. 20 at 365 (A.C.).

se Id.; and Re Snyder [1927] 2 W.W.R. 240, 38 B.C.R. 336, [1927] 3 D.L.R. 151 (C.A.).

s7 Re Lyon and Lyon, supra, n. 50; and Leatherdale v. Fergusson (1964) 50 W.W.R. 700, 50 D.L.R. (2d) 182 (Man. C.A.).

ss Re Shand (1928) 62 O.L.R. 145, 34 O.W.N. 22.

59 McKee v. McKee, supra, n. 20 (P.C.).
} 